\title{
THE INFLUENCE OF CHRISTIANITY ON GRAECO-ROMAN MEDICINE UP TO THE RENAISSANCE
}

\author{
F P Retief \& L Cilliers (University of the Free State)
}

Christianity made its appearance at a time when religion, even magic, played a much more important role in health care than it does today. As Ferngren and Amundsen (1994:2957-2960) point out, this is not necessarily because the ancients were more credulous or superstitious than we are today, but mainly because they realized that so much of life, including ill health, lay beyond their control. Ancient civilizations on the shores of the Mediterranean believed in a multitude of gods or goddesses, magical forces and supernatural powers which affected their health. But at least since the days of Homer there also existed physicians who practised some form of empirical medicine, and during the $5^{\text {th }}$ and $4^{\text {th }}$ centuries BC the Hippocratic doctors established the foundations of rational or scientific medicine as we know it today, where superstition, magic and supernatural factors were not relevant.

Health care based on the teachings of Christ, as recorded in the New Testament, is primarily of a religious nature (Wassermann 1997:6-12). Although this need not imply conflict with secular medicine, history tells us that antagonism did soon arise, and despite the fact that positive influences are acknowledged, the view that the Christian church eventually retarded the advance of medical science (in Medieval times in particular) is a common one (Porter 1997:110-112). However, Nutton (1984:1), Avalos (1999:7-15) and others have warned that much research still needs to be done to verify traditional statements on this issue. In this study we have endeavoured to analyse the intricate interplay between the Christian church and rational medicine (as represented by Graeco-Roman medical concepts) during the first 1500 years of Christendom.

\section{Health care systems at the time of Christ}

1. Judaism.

Christianity's health concepts were moulded on the traditional Hebrew health care system, based on monotheistic principles, as mainly outlined in the Pentateuch. In essence this was a ritualistic community health care system with more than 600 commands and bans, 213 of which are described in Leviticus (Wassermann 1997:5165; Avalos 1999:33-45, 62, 69). Purity played an important role and all illness and cure were solely controlled by Yahweh, although a dualistic concept involving Satan did appear after the Babylonian exile. Priests and prophets acted as healers. Doctors are occasionally mentioned in the Old Testament (e.g. Gen. 50:1-3; Job 13:4; Jer. 8:22; II Chron. 16:12), often in an unfavourable light. There is mention of miracle cures by prophets (e.g. II Kings 20:7-11; II Kings 5:14) and raising from the dead (I Kings 17:24). Lepers were banned from society, although it is now generally agreed that tsaraat, the Hebrew word later translated as leprosy, originally referred to a variety of non-specific afflictions considered to have been sent by God to indicate his 
displeasure (Wassermann 1997:51-65). Avalos (1999:75, 76) suggests that despite their strict monotheistic religion, many Hebrews visited sorcerers and made use of minor gods, figurines and amulets as curing aids. At the time of Christ, Judaism was significantly influenced by a post-Alexandrian Hellenistic culture in Palestine, and Jews almost certainly visited pagan healers in temples, as well as secular physicians (Wassermann 1997:163, 164). In fact, by the $2^{\text {nd }}$ century BC Jewish medical practitioners who had adopted Greek empiric medicine, in so far as it was not antithetical to Jewish religion, were common (Ferngren and Amundsen 1994:2958).

2. Other religions.

From early antiquity religions influenced health care systems, but it is also true that even in early Egypt and Mesopotamia there were already physicians practising elementary empirical (secular) medicine.

At the time of Christ the ancient Egyptian Isis-religion was still widely popular and her shrines could be found in early centres of Christianity, like Ephesus, Athens, Philippi and Corinth. Popularised by Plutarch, she was seen as a goddess of healing, and the temples of Isis were often associated with Serapis, a healing deity of unsure origin. The Serapeum of Alexandria was one of the most famous healing sanctuaries of the ancient world (Wassermann 1997:16, Avalos 1999:51-53).

The Mesopotamians had the healing gods Ninib and Ninazu, and the goddess Gula. She had temples in various centres in the Middle East and a reputation for resurrecting the dead. Mithraism, named after one Mithras, possibly derived from an older Persian deity of the same name, had cave shrines as its hall mark and was originally associated with healing rituals, not unlike early Christianity. Originating in the $1^{\text {st }}$ century, the cult lasted 400 years, but recent research shows little evidence of interference with Christianity (Avalos 1999:54).

Asclepius, Greek god of health and patron saint of physicians, was popularised in the $5^{\text {th }}$ century BC, when Asclepian temples of healing first appeared in Epidaurus, and later spread widely through Mediterranean countries. The shrines were visited by pilgrims who mainly came for miraculous cures by means of incubation - the practice of sleeping in the temple while waiting for healing instructions through dreams. There is evidence that dietary regimes, exercise therapy and encouragement to adopt healthy life styles, often formed part of the therapeutic ritual. These Asclepieia were popular in Roman times, in part because they offered healing without charge, and accepted all, irrespective of social standing (Avalos 1999:48-81, Major 1954:103-110). Healing by incubation sleep was also popular with a variety of other so-called oriental mystery religions, where magic and astrology played a role in association with the widespread use of amulets, charms and incantations (Ferngren and Amundsen 1994:2959).

\section{Secular Graeco-Roman Medicine.}

By common consensus modern scientific medicine has its roots in Greek medicine of the $5^{\text {th }}$ century $\mathrm{BC}$, and the Hippocratic School in particular. It may be called rational medicine in so far as it was based on natural and demonstrable phenomena, and contemporary (albeit defective) knowledge of human physiology and anatomy 
(Avalos 1999:55-58; Ferngren and Amundsen 1994:2958). Supernatural powers, magic and superstition were excluded from the medical system, although a modicum of religion was retained. In the Hippocratic Oath, for instance, homage is still paid to Asclepius. Philosophers like Aristotle and his Peripatetic School later made useful contributions, but the major scientific progress before the Christian era came from the Alexandrian School of Medicine in the $3^{\text {rd }}$ century BC, and Herophilus (who first dissected human cadavers) and Eristratus in particular. The Dogmatic, Empiric and Methodist movements all had their contributors to the development of rational medicine, and during the first century the Roman nobleman Celsus (probably not a physician himself) wrote an extraordinary encyclopædia of contemporary medical, knowledge the De re medicina. This summarized secular medicine of the time, the beginning of Christianity. At that stage certain basic surgical techniques and the treatment of injuries and fractures were reasonably developed. As far as the etiology of internal diseases was concerned, explanations revolved around a presumed imbalance of 4 bodily humors (blood, phlegm, yellow bile and black bile), 4 elements (earth, air, fire and water) and 4 qualities (hot, cold, dry and moist). Prevention of illness was important, and treatment lay in restoring disturbed balances by way of diet, exercise, baths and a variety of drugs (the majority of which would have been quite ineffectual). There were no hospitals for the civic sick, and Hippocratic medicine (even Judaic traditions) allowed physicians to withdraw from treatment of incurable disease (Aitken et al. 1984:32).

In the second century Rufus of Ephesus (Major 1954:182-184) and Soranus (Major 1954:185-187) added to medical knowledge, but it was the colossus Galen (Major 1954:188-202) who consolidated Hippocratic medicine and cast it into a mould which remained largely unchanged till the Renaissance in the $15^{\text {th }}$ century. Galen, whose immense medical bibliography (in Greek) consisted of more than 2 500,000 words, based his clinical medicine on health science as understood in his day, insisted on a honourable and professional code of conduct for physicians, and rejected all magic, miracles and superstition.

\section{Basis of Christian health care}

The actions and teachings of Christ and their interpretation by the evangelists and authors of epistles in the New Testament, laid the foundations of early Christian health care (Wassermann 1997:107-111; Ferngren \& Amundsen 1994:2961; Avalos 1999:75).

As in Judaism, the new religion laid great stress on the role of a monotheistic God who, in the final instance, controlled all illness. Health care thus had a strong religious bias, and belief in an omnipotent God lay at the root of healing. During his ministry on earth, Jesus had raised people from the dead, and cured a large number of persons and a variety of illnesses. These were accepted as miraculous cures, and for a while after his death (according to Acts) his apostles also healed miraculously in the name of God. Although mention is occasionally made of anointment (James 5:15), laying on of hands (Mark 16:18), fasting (Mark 9:29), drinking of wine (I Tim. 4:23) and even the use of a simple eye preparation (John 9:6; Rev. 3:18), the healing 
process was based on the elementary notion that faith alone could cure illness (Avalos 1999:75). In James 5:14-15 the ill are advised to visit the church elder who will effect cure by way of prayer and anointment. Etiology of disease was unimportant, since treatment was the same for all illnesses. Exorcism is strikingly described in the Gospels, but Ferngren \& Amundsen (1994:2966) make the point that through exorcism Jesus cured diseases caused by demonic activity, and not demonic possession. The role of exorcism in Christian dogma has remained a controversial issue up to present times. Secular physicians are rarely mentioned in the New Testament, and then often with a negative connotation (Luke 9:43), although Paul did refer to Luke as the beloved physician (Col. 4:14). Central to the New Testament's understanding of illness, is the development of a Christian theology of suffering (Ferngren \& Amundsen 1994:2962, 2963, 2987; Amundsen 1982:334-340). Whilst living in an imperfect world of sin, the Christian should expect and accept suffering, and know that not all illnesses would be cured. Although the concept of illness being caused by sin figures prominently in the Gospels (John 9:2), few of Christ's miracle cures were actually associated with winning people's souls.

\section{Christianity and secular medicine: $1^{\text {st }}-3^{\text {rd }}$ Centuries}

Evidence shows that early Christianity probably showed little animosity towards Graeco-Roman medicine, although Nutton and others have warned that more in depth research should be done in this field (Nutton 1984:2). There was indeed nothing in Hippocratic medicine which could be seen as seriously antithetical to Christian theology or practice, and it is likely that Christians took to secular medicine very early on. Most pagan religions of the time had an element of supernatural healing which complemented rather than competed with secular medicine (Ferngren \& Amundsen 1994:2963-5). There is however, no mention by name of a Christian physician until the late second century when one Alexander of Phrygia suffered martyrdom for his faith (Ferngren \& Amundsen 1994:2965). It is thus probable that in illness Christians visited their priests as well as physicians. The majority of Church Fathers found it possible to accommodate medicine in the new religion (Nutton 1984:5; Amundsen 1982:333-340, 350). Ambrose and others would however, reprimand Christians who prayed for healing only when the efforts of the physician failed. Amundsen gives an excellent overview of the views and teachings of individual Church Fathers of the time (1982:326-350).

The new Christian ethic of almsgiving, piety and caring for the old, poor and infirm, soon gained a prominence for the church which was out of proportion to the number of Christians in the Roman world (Brown 1997:31). Visiting the sick, elderly and poor was a duty incumbent on all Christians (Ferngren \& Amundsen 1994:2971). The modern hospital concept had its origin in the early Christian communities (Cilliers \& Retief 2002) and Sigerist states that their compassion and long term care for suffering was fundamentally different from anything known before (Sigerist 1943:68-70). Neither the pagan temples nor the mystery religious created a caring community like that of early Christianity (Ferngren \& Amundsen 1994:2976). In time even those Roman emperors who had instituted persecution of Christendom, 
commented favourably on the Christians' unstinting assistance to all victims of the epidemics (probably small pox) which ravaged the Roman empire during the $2^{\text {nd }}, 3^{\text {rd }}$ and $4^{\text {th }}$ centuries (Retief \& Cilliers 2000:267-272, Ferngren \& Amundsen 1994: 2974). Christian health ministration was also continued in spite of patients' poor prognosis for cure - situations in which patients would probably have been abandoned by Hippocratic medicine.

But gradually latent tension arose between early Christianity and GraecoRoman medicine (Nutton 1984:5) based mainly on

(a) criticism that too much trust was being placed on physicians rather than God;

(b) neglect of the spiritual value of sickness (believers should accept suffering);

(c) increasing desire for healing through the use of supernatural means in view of growing belief in the demonic cause of illness.

During the $2^{\text {nd }}$ century Galen's medicine was approved by a group of Christians led by Theodorus of Byzantium (Ferngren \& Amundsen 1994: 2974), in spite of Galen's criticism of Christianity when he said: "If I had in mind people who taught their pupils in the same way as the followers of Moses and Christ teach theirs - for they order them to accept everything on faith - I should not have given you a definition" (Walzer 1949:15). Others, like Tertullian and the heretic Marcion in particular, found secular medicine unacceptable (Ferngren \& Amundsen 1994: 2964). Origen attacked Celsus' medical system, but in agreement with the majority of church leaders, approved of treatment by physicians as long as the spiritual side of healing was not neglected (Amundsen 1982:333-340). Tatian was hostile, but Ferngren \& Amundsen (1994:2963-4) suggest that the hostility was really in reaction to perceived magical practices. In the late $3^{\text {rd }}$ century, Eusebius, bishop of Caesarea in the reign of Emperor Diocletian (who instituted severe Christian persecution in 303) approved of Hippocrates, but wrote against perceived anti-Christian sentiments in the teachings of many Greek philosophers; he warned that Galen was treated as a god by many physicians (Eusebius, Eccl.Hist. V 8, 6-17).

However, towards the end of the $2^{\text {nd }}$ century significant shifts in basic Christian theological thinking had set in, including greater emphasis on demonic possession as cause of disease (and exorcism as treatment) and miracle cures. Up till then miraculous cures were considered to have been confined to the Gospel era (Ferngren \& Amundsen 1994:2977). Gradually this would progressively distance Christians from secular medicine.

In the time of Cyprian and Anastasius of Sinai ( $3^{\text {rd }}$ century), it was debated whether avoiding epidemic disease was scripturally acceptable, in view of the Church's dogma of the virtue of suffering (Nutton 1984:8).

Christianity and secular medicine: $4^{\text {th }}-6^{\text {th }}$ Centuries

This period which included the fall of the Western Roman Empire in 476, also brought significant changes to the organization of Christianity. Diocletian's persecutions at the turn of the $4^{\text {th }}$ century were followed quite dramatically by Constantine's victory at the Milvian bridge and the proclamation of Christianity as 
state religion in 313. Constantine's successors, Constantius II and Theodosius, affirmed the new religion, forbade public sacrifices, closed pagan temples and even colluded in acts of violence against cult sites, including the destruction of Alexandria's Serapeum in 391. It is unlikely that more than $10 \%$ of Rome's population was Christian at this stage, but nominally at least, the state's administration became Christian (Brown 1997:22-40).

The Church experienced progressive change. The creation of Manichaeism in 310 (the first new religious movement to emerge from Christianity) introduced a cult of ascetic "apostolic" faith, and facilitated the widespread appearance of hermits and "holy men" (Brown 1997:41, 42). With this came a growing emphasis on supernatural healing, exorcism and apostolic charismata, already introduced by the Phrygian Montanists in the late $2^{\text {nd }}$ century. Tertullian, for instance, who became a Montanist late in life, laid great faith in a Christian woman in Carthage who possessed the supernatural gift of miraculous healing (Ferngren \& Amundsen 1994:2967). Magic which had been universally condemned by early Christian authorities, now emerged in the popularisation of amulets, charms and healing incantations (Ferngren \& Amundsen 1994:2968). This was initially denounced by church leaders like Chrysostom and Augustine, but gradually the dividing line between acceptable supernatural healing and magic became blurred, and eventually even Augustine exhibited ambivalence in these matters (Keenan 1936:184). In addition to claims of miraculous healing by ascetics in particular, there arose a new spiritual elite venerated for their self-denial and ability to perform miracles. Origen, Basil and Macarius initiated a two-tiered concept in which it was quite in order for ordinary Christians to consult secular physicians, but exalted Christians were expected to believe solely in religious healing (Amundsen 1982:338, 339, 347).

The concept of healing saints, originating with the medical martyrs, Cosmas and Damian ( $4^{\text {th }}$ century), developed into a veritable pantheon of healing saints. Eventually saints were later even dedicated to specific diseases (Ferngren \& Amundsen 1994:2969; Brown 1997:105-107; Porter 1997:110-112). With the saints came healing shrines (often at the sites of earlier pagan healing temples) (Nutton 1984:7) and the use of healing relics associated with the saints (Brown 1997:105, 108-110). At the Councils of Ephesus (431) and Chalcedon (452), so-called heretical sects were identified and excommunicated - including the Monophysite movement (popular in Byzantium) and the Syriac-speaking Nestorian Christians (Brown 1997:113-118). The latter continued to play a significant role in medicine when they withdrew to found a medical school in Edessa. Subsequently banished from there in 489 , they scattered far and wide, and eventually found asylum in Persia where a flourishing medical school was established in Jundi-Shapur. This school subsequently exerted a profound influence on Islamic medicine (Major 1954:227).

The church's movement towards supernatural and magical healing impacted negatively on orthodox medicine. Nutton (1984:8) suggests that in order to accommodate this development, many secular doctors became less "scientific" in their approach to medicine. The extent to which this official stance of the church actually affected the ordinary citizen's health care, is difficult to assess. Church 
leaders like Basil ( $4^{\text {th }}$ century) Diadochus ( $5^{\text {th }}$ century), John of Ephesus $\left(6^{\text {th }}\right.$ century) (Nutton 1984:5, 6) and Cassiodorus (6 ${ }^{\text {th }}$ century) (Aitken et al. 1984:33) supported secular physicians whilst warning against over-confidence in secular medicine. Theodore of Sykeon ( $5^{\text {th }}$ century) and others were highly critical of physicians (Horden 1982:1-13). Despite the state's official Christian character, a large number of prominent physicians were blatantly pagan, or had pagan sympathies, e.g. Oribasius, Gesius and Agapius of Alexandria (Nutton 1984:6). The Church always suspected the medical profession of being a stronghold of paganism and heresy (Horden 1982:113), but Cassiodorus, Aëtius of Amida, Paul of Aegina and Alexander of Tralles were professing Christians or had strong Christian sympathies (Aitken et al. 1984:33-4). Even then Nutton (1984:8) points out that physicians like Alexander of Tralles also made use of amulets and charms in their treatment.

During this time the rise of monasticism was responsible for the creation of monasteries - often with associated medical facilities and hospitals which were naturally under religious control. Treatment, by lay physicians or monks trained in medicine, was administered to inmates as well as the civic population, and in due course physicians practised outside the realm of the church. Some of these monasteries, like that of St. Basil in Caesarea and St. Benedict in Monte Casino, became centres of medical excellence in the $4^{\text {th }}-5^{\text {th }}$ centuries. Here classical texts were collected and copied, and some medical teaching was done (Aitken et al. 1984:9-13). None of these could, however, compare with the great medical teaching institutions which later arose in Islam (Nutton 1984:10). Nutton also makes the point that physicians in late antiquity became professionally better organised, and developed prominent public profiles as civil servants, ambassadors, church leaders, even saints (Nutton 1984:12).

With the possible exception of Oribasius ( $4^{\text {th }}$ century), Aëtius $\left(6^{\text {th }}\right.$ century) and Paul of Aegina ( $7^{\text {th }}$ century), no physicians since Galen in the $2^{\text {nd }}$ century added significantly to the existing basis of medical knowledge (Guthrie 1958:79-80).

Early Middle Ages: $7^{\text {th }}-12^{\text {th }}$ Centuries

After the fall of Rome, Constantinople (Byzantium) became the capital of the GraecoRoman world although the papal presence did not leave Rome. In the $11^{\text {th }}$ century the Western (Rome) and Eastern (Constantinople) sections of the Christian Church separated permanently because of irreconcilable differences regarding the nature of the Trinity. The powerful Church exerted growing pressure on virtually all aspects of community life and in general this was unfortunately not conducive to original scientific endeavour and free thought - including the profession of medicine (Nutton 1984:1; Brown 1997:320; Aitken et al. 1984:32). During the so-called "Iconoclastic controversy" (740-843) the Church eventually accepted images of holy individuals as privileged artefacts, singled out for particular devotion. This was condemned as idolatry by the Jews and Islam, but in Christendom it lead to the increased acceptance of magical healing, seen as a legitimate supernatural phenomenon potentiated by saints, shrines and holy relics (Brown, 1997:238-240). Pilgrimages ensued to healing shrines like that of Rocamadour in Southern France with its black Madonna (Mason 
1982:39-54; Sumpton 1975:6, 76, 78, 80, 99-102; Biller 1982:55-77). Healing of the body became part of a repentance ritual which could not succeed fully unless the soul was also liberated from sin. Healing shrines became money-spinners for the Church (Mason 1982:39-54; Sumpton 1975:6, 76, 78, 80, 99-102; Biller 1982:55-77). In its most extreme form, this eventually led to prohibitions of Jewish doctors inter alia from some Church hospitals (Porter 1997: 110), and the delaying of treatment until after a confession had been heard by a priest (Palmer 1982:79-99). When Christian groupings like the Waldensian Order proclaimed against saints, shrines and relics, they were ruthlessly persecuted as heretics by the Inquisition set up in the $13^{\text {th }}$ century to purge Christianity of heresies. The Spanish Inquisition remained nominally in existence up to the $18^{\text {th }}$ century. During the $12^{\text {th }}$ century the theology of suffering which determined that lepers, victims of other chronic diseases and periodic epidemics, should carry their afflictions with grace and repent for their sins, led to serious conflicts between Church and lay medicine. While secular health authorities insisted on isolation of the sick and avoidance of mass gatherings, the Church persisted with public shows of repentance and religious marches to glorify God and confound Satan. However, Palmer (1982:79-99) states that throughout there was also a large degree of effective co-operation between scientists and the clergy, and with progressive secularisation of the health profession these problems gradually disappeared (Aitken et al 1984:37).

Medical schools were also appearing at the new Medieval universities of Salerno (11 ${ }^{\text {th }}$ century) and Montpellier (12 ${ }^{\text {th }}$ century) (Aitken et al 1984:37-40; Major 1954:271-312). Universities in Paris, Oxford, Cambridge, Bologna and Padua would follow in the $13^{\text {th }}-14^{\text {th }}$ centuries (Major 1954:312-333). Although tentatively under Church control, these institutions based their curricula on classical secular medicine with a strong input from Islamic sources, as will be shown.

Islam: $7^{\text {th }}-13^{\text {th }}$ Centuries

One century after Mohammed had unleashed his Islamic revolution in 632, the conquering diminished, and under enlightened caliphs like Harun al Rashid, the "Golden Age of Islam" which terminated with the Mongol sack of Baghdad in 1258, was launched (Major 1954: 256-261). This period was characterized by great intellectual activity, and medicine, in particular, was preserved and enhanced, while Europe, under control of the Christian Church, showed little scientific advancement. Islam's significant medical contributions were facilitated by early contributions from the Syriac-speaking Nestorian Christians who had established a medical school in Jundi-Shapur (or Nisibis, Persia) during the $7^{\text {th }}$ century. When Islam conquered Persia these physicians were encouraged to stay and assist with medical development (Major 1954:227; Brown 1997:170-180). Of this period Meyerhof says "that Islamic medicine and science reflected the light of the Hellenic sun when its day had fled, and that they shone like a moon, illuminating the darkest night of the European Middle Ages; that some bright stars lent their own light, and that moon and stars alike faded at the dawn of a new day - the Renaissance" (Major 1954:227). 
In 765 Jurjis, chief of physicians at Jundi-Shapur, so impressed the caliph, alMansur, that he became court physician - and for the next 250 years Christian Nestorians like Serapion, Salmouih ben Bayan and the famous Bukt-Yishu family were pre-eminent in Arabian medicine, including 7 royal physicians. Among the latter were Mesüe and Hunayn, who translated Greek and Syriac medical texts into Arabic. During the $9^{\text {th }}-10^{\text {th }}$ centuries eminent teaching hospitals arose inter alia in Baghdad, Damascus and Cordoba (Spain) at which scholars of all religions and nationalities from Europe and elsewhere were encouraged to study. For 4 centuries the lingua franca of medical advancement became Arabic, as eminent physicians from Islam like Rhazes, Albussasis, Avicenna, Avenzoar, Averroës and the great Jewish doctor, Maimonides, contributed significantly to scientific medicine. Eventually in the $11^{\text {th }}-12^{\text {th }}$ centuries much of this knowledge would flow back (in Arabic) to Europe's first medical schools at Salerno and Montpellier, via Christian and Jewish doctors. By the late Middle Ages original Greek medical classics which had disappeared from European libraries (where the Latin speaking community often could not read them) were retrieved from Islam as Arabic translations (Aitken et al. 1984:34-37; Major 1954:225-261).

\section{Late Middle Ages and Renaissance: $13^{\text {th }}-16^{\text {th }}$ Centuries}

The emergence of new medical knowledge from the young universities of Salerno, Montpellier and others, as well as a progressive secularisation of health care as civic hospitals appeared all over Europe and public physicians replaced monastic medicine, lead to new tension between Church and secular medicine (Aitken et al. 1984:37). This was not so much because the Church repressed scientific medical advancement but rather because its dictum "divine before temporal", became difficult to implement (Nutton 1984:1, 2). Gradually losing its moral and intellectual leadership, the Church retained its wealth, privileges and persecuting power. The Inquisition, introduced in the $13^{\text {th }}$ century to define and deal with heresies, also affected medicine as the Church adopted a medical dogma based on aspects of mainly Galenic and Hippocratic teaching. Doctors tried for suspected heresies in their medical writings included D'Abano in 1315 who died during the trial; however, his remains were exhumed and burnt at the stake (Sigerist 1971:95-99). Servetus also died at the stake for unacceptable criticism of Galen as well as theological heresy (1553) (Porter 1997:184). In all, the Inquisition probably influenced medicine indirectly rather than directly by hampering education through the banning of certain texts, restrictions on student intake at religious universities, and exclusion of heretic teachers (Jews in particular). These problems specifically affected Spain (Kamen 1998:107-139).

The Lateran Council of 1215 forbade physicians not approved by the Church from attending the sick, but it was soon clear that this ban (aimed primarily at Jewish doctors) could not be enforced. The Council also barred clerics in higher orders (monk physicians) from operating and practising for gain (Porter 1997:110-112). Bernard of Clairvaux ( $12^{\text {th }}$ century) initiated this action against monastic medicine in order to ensure greater spiritual rather than medical activity in monasteries. He was also very critical of physicians, stating that there are "better cures in the School of 
Christ than in the School of Galen" (Dawfrey 1982:25-38). The Crusades, interestingly enough, had a beneficial effect on health care when the Knights of St. John in the $13^{\text {th }}$ century were responsible for the building of hospitals all over the Mediterranean and in German speaking countries (Major 1984:267).

The "Black Death" (bubonic plague) which ravaged Europe in 1348 clearly demonstrated the medical profession's ignorance of the cause and management of epidemic disease. According to a famous physician of the time, Guy de Chauliac, it was caused by the conjunction of Saturn, Jupiter and Mars, and the community largely resorted to supernatural aid. In the end the Jews were blamed and in spite of papal Bulls declaring them innocent, a massacre ensued in Switzerland and Bavaria (Major 1954:337-338).

During the $15^{\text {th }}$ century a combination of factors such as the migration of Greek scholars to the West after the fall of Constantinople in 1453, and the discovery of the printing press in 1454, caused an explosion of knowledge which had been building up since the disintegration of the Islamic Empire in the $13^{\text {th }}$ century (Major 1954:357-8). This triggered the cultural and scientific rebirth of Europe which we know as the Renaissance $\left(15^{\text {th }}-16^{\text {th }}\right.$ century). Conservative elements in the Church resisted the new tide, and in the field of medicine discoveries by Vesalius, Paracelsus, Fallopio, Sylvius and others (demonstrating many fallacies in the classical teachings of Galen in particular) caused resentment and reaction (Major 1954:357-457). However, the old order was truly gone, and when Martin Luther initiated the Reformation in 1517, and Henry VIII broke with the Vatican, two decades later, the Christian church had lost its hegemony. In due course Christianity and medicine would be re-aligned according to the realities of the Age of Enlightenment.

\section{Overview}

Early Christianity co-existed in relative harmony with empirical medicine based on the Hippocratic ethos, whilst emphasising the healing powers of an omnipotent God, as demonstrated during Christ's ministry on earth. Church fathers like Justin, Clement of Alexandria, Origen, Augustine, John Chrysostom and others were able to reconcile the new religion with much of the pre-Christian Greek culture. Dissenters like Tertullian and Tatian were in the minority. It was taught that God gave doctors the wisdom to cure disease, but that He could cure without doctors (Amundsen 1982:33340 ). During the late $2^{\text {nd }}$ century, possibly due to the hardships and epidemics of the Antonine period, a new culture set in, characterized by increasing emphasis on miraculous cures (previously considered as having being confined to the Gospel era), demonic possession and exorcism. The $4^{\text {th }}$ century brought radical changes. State persecution was replaced by Constantine's legitimatisation of Christianity and its elevation to state religion. Although only a small percentage of the Roman population were Christians at that stage, the Church grew from strength to strength, with increasing influence on affairs of state. Internal disagreement on theological issues led to the appearance of dissenting groupings, like Manichaeism (giving rise to asceticism, hermits and "holy men") and the Syriac-speaking Nestorian Christians who, on banishment, moved to the East and Persia in particular. The very open, 
caring, democratic Christian community of the $1^{\text {st }}$ century gradually turned into a rigid, powerful organisation which regulated the lives of the populace according to its religious views (Cahill 1995: 61-2). The supposed healing powers of medical saints, holy shrines, relics and images of saints, became theological dogma.

In the field of health care asceticism had given rise to monastic medicine monasteries with medical faculties, usually run by monk-physicians. Hospitals like that of St. Basil in Caesarea and Monte Casino in Italy became excellent health care centres where Greek classical manuscripts were collected and copied, and a modicum of medical teaching done (subject to acceptable religions dogma). With the fall of Rome in 476, Constantinople (Byzantium) became the seat of Greco-Roman civilisation. The Middle Ages brought stagnation of scientific and cultural development in Europe, which in the medical field, increased the importance of monastic institutions. Secular medical contributions did not cease but remained at a low ebb.

The "Golden Age of Islam" $\left(9^{\text {th }}-12^{\text {th }}\right.$ centuries $)$ however, was associated with a remarkable upswing of scientific and cultural development. Assisted by the Nestorian Christian doctors from Persia, Greek medical classics were translated into Arabic, and taught at great teaching hospitals in cities like Baghdad, Damascus and Cordoba. Whilst European medicine had stagnated, the science thus expanded in this region, which became the centre of excellence for international study. With the disintegration of the Islamic empire after the $12^{\text {th }}$ century, this expertise flowed back to the early European universities at Salerno and Montpellier. Here mostly Christian and Jewish doctors reintroduced the original classical teaching, and also conveyed original Arabic contributions.

This influx of new knowledge and theories (emanating inter alia from a heathen source, Islam) was resented by orthodox church leaders and some of it equated with heresy. Growing secularisation of health care, establishment of civic hospitals beside the monastic institutions, and the increased employment of secular doctors, also decreased the Church's grip on medical orthodoxy. Through the Inquisition attempts were made to stem the tide but the Renaissance and subsequent Reformation, which divided the Church's hegemony, progressively neutralised the opposition of conservative Church elements.

In summary we may say that Christianity's first great contributions to medicine lay in the early establishment of caring communities, which brought personalized medical care to the sick, irrespective of nationality, social status, age or disease (i.a. virulent epidemic diseases). This ultimately led to the creation of hospitals as we know them today. Monastic institutions also served as health centres with limited teaching activities, and libraries of classical information when Medieval Europe was paying little attention to the advancement of knowledge. It is also an ironic truth that the Nestorian Christians, banned from the Church in the $5^{\text {th }}$ century, were instrumental in the establishment of empirical medicine in Islam.

On the negative side the Church's decision to accept the healing powers of saints and their shrines and relics as theological dogma after the $5^{\text {th }}$ century, distanced it from empirical medicine. There is reason to believe that the Christian ill continued 
to make use of both secular medicine and religious healing. The latter was seen as a form of legitimate supernatural cure and not magic (Avalos 1999:81-87). The precise role of faith healing has indeed remained a problem for many Christians through the ages, even up to the $20^{\text {th }}$ century (Mews 1982: 299-331). During the Middle Ages the Church's authoritative hand did not encourage original scientific thought outside the realms of its predestined medical dogma based largely on the teaching of the Greek masters and Galen in particular. Dissent was treated with growing displeasure, even ex-communication, and once it was equated with heresy (after the $13^{\text {th }}$ century), death at the stake could be the punishment. There is little evidence that this happened often, but restrictions placed on the medical fraternity by the Inquisition (in Spain particularly) did lead to serious dissatisfaction, even from devout members of the Church (Kamen 1998:107-139). Jewish doctors were specifically targeted, but mainly due to their professional excellence they could not be excluded from society (Porter 1997: 110-112). The curious intellectual lethargy which characterized Medieval times, was, however, of complex causation and cannot be attributed only to a very conservative Church hierarchy.

\section{BIBLIOGRAPHY}

Aitken, J T, Fuller, H W C \& Johnson, D 1984. The influence of Christians in Medicine. London: Intervarsity Press.

Amundsen, D W 1982. Medicine and faith in early Christianity. Bull. Hist. of Med. 56. 326-350.

Avalos, H 1999. Health care and the rise of Christianity. Massachussets:Hendrickson Publ.

Biller, P 1982. Curate infirmos: The medieval Waldensian practice of medicine. In: The Church and Healing Vol.19 (ed. Sheils W J), Oxford: Blackwell.

Brown, P 1997. The rise of Western Christendom. Oxford: Blackwell.

Cilliers, L \& Retief, F P 2000. The evolution of hospitals from antiquity to the Renaissance. Forthcoming in Curationis.

Cahill, T 1995. How the Irish saved civilisation. London: Hodder \& Stroughton.

Dawtrey, A F 1982. The modus medendi and the Benedictine Order in Anglo-Norman England. In: The Church and Healing Vol. 19 (ed. Sheils W J), Oxford: Blackwell.

Ferngren, G B \& Amundsen, D W 1994. Medicine and Christianity in the Roman empire: Compatibilities and tensions. In: Aufstieg und Niedergang der römischen Welt II. 37.3, pp. 2957-2980.

Guthrie, D 1958. A history of medicine. , London: Nelson \& Sons.

Horden, P 1982. Saints and doctors in the early Byzantine Empire. In: The Church and Healing, Vol. 19 (ed. Sheils W J), Oxford: Blackwell.

Kamen, H 1998. The Spanish Inquisition. London: Orion Publ.

Keenan, M E 1936. Augustine and the medical profession. Trans. Of the American Philological Assoc. 67. 184. 
Major, R H 1954. A history of medicine. Vol. 1, Springfield: Charles Thomas Publ.

Mason, E 1982. Rocamadour in Quercy above all the Churches. In: The Church and Healing Vol. 19 (ed. Sheils W J), Oxford: Blackwell.

Mews, S 1982. The revival of spiritual healing in the Church of England, 1920-1926. In: The Church and Healing Vol. 19 (ed. Sheils W J) Blackwell: Oxford.

Nutton, V 1984. From Galen to Alexander. Aspects of medicine and medical practice in late antiquity. In: Symposium on Byzantine Medicine (ed. Scarborough J), Dumbarton Oaks Papers, no 38. Washington, D.C: Dumbarton Oaks Research Library and Collection.

Palmer, R 1982. The Church, leprosy and plague in medieval and early modern Europe. In: The Church and Healing Vol. 19 (ed. Sheils W J), Oxford: Blackwell.

Porter, 1997. The greatest benefit for mankind. , London: Harper Collins.

Retief, F P \& Cilliers, L 2000. Epidemics of the Roman Empire, 27 BC-AD 467. S.A. Med. Journal 90 (3) 267-272.

Sigerist, H E 1955. A history of medicine. Vol. 1. London: Oxford Univ. Press.

Sigerist, H E 1943. Civilization and disease. Ithaca: Ithaca Press.

Sigerist, H E 1971. The great doctors. New York:Dorea Publ.

Sumpton, J J 1975. Pilgrimage: an image of medieval religion. London: Oxford Press.

Walzer, R 1949. Galen on Jews and Christians. London: Oxford Univ. Press.

Wassermann, H P 1997. Geneeskunde in die Bybel. Pretoria: Van Schaik. 